the spread of electrification. In electric power stations, lignite, oil, coke-oven and blast furnace gas are used as well as coal and water-power. In France, electrification is from certain points of view imperative as France has to purchase coal and oil from abroad whilst it possesses great internal water-power resources. The consumption of fuel by French railways amounts to 42 million tons, of which 30 millions has to be imported. At the present time, France utilises 8,000 million kilowatt hours of energy generated by water-power or about 20 per cent of its maximum potential water-power resources. In Italy the policy of exploiting the natural wealth of the country has been systematically pursued. More than 1,200 miles of Italian railways are electrified and 3,000 miles are in progress. Similar, but less far-reaching programmes, have been prepared and are being carried out in Switzerland, Sweden and Bavaria. The electrical machinery employed is almost entirely automatic and entails operation, maintenance and repair charges considerably lower than steam locomotives.

\section{Centenary of the Great Western Railway}

ON August 31, 1835, after an unduly protracted and very expensive Parliamentary struggle, the Royal Assent was given to the Bill authorising the construction of the railway between Bristol and London, to which two years earlier the name of the Great Western Railway had been given. Notable among British railways for many reasons, the Great Western Railway as it is to-day has a fine record of achievement, and last week the centenary of the passing of the Bill which brought it into being was commemorated in various ways. On the evening of August 30, the B.B.C. included in its programme an account of the railway and its many activities, while on August 31, The Times issued a Great Western Railway Centenary Number as a special supplement, of 28 full-sized pages. The forty articles in this supplement include not only sketches of the history of the line, a biography of Brunel and a review of locomotives and rolling stock, but also others dealing with co-operation in transport, speed, safety and comfort in travel and the organisation of a great railway. As is well known, when planning the Great Western line, Brunel adopted the $7 \mathrm{ft}$. or broad gauge, as compared with the $4 \mathrm{ft}$. $8 \frac{1}{2} \mathrm{in}$. or narrow gauge, as used by the Stephensons and others, and it was this that gave rise to the famous "battle of the gauges". When that battle was at its height, a Royal Commission reported that the broad gauge was superior for speed and steady running, and for the greater capacity of the engines, but as there were then 1900 miles of narrow gauge line in existence as compared with only 274 miles of broad gauge, the verdict was given in favour of the former. This and other matters are all dealt with in an interesting manner in The Times supplement, which will remain of permanent value to all students of transport.

\section{International Commission of Agriculture}

The International Commission of Agriculture (International Union of Agricultural Associations) recently held its general assembly at Brussels and
Gembloux (Belgium) under the chairmanship of the Marquis de Vogüé (France), president. Among the problems discussed were the organisation of agricultural production under planned economy, edible fats, limitation of pig breeding and fattening (with special reference to attempts made in Denmark and Holland). The assembly devoted special attention to the present condition of agriculture. It came to the conclusion that in spite of the fact that useful measures have been taken in several countries since 1932, conditions of agriculture have grown worse. The Commission is convinced that the two main problems to be solved in order to overcome the agricultural crisis are the wheat problem and the edible fats problem : on one hand the London Wheat Agreement (1933) should be prolonged and improved; on the other, the older civilised countries should take measures or improve the existing measures in order to prevent consumption of tropical fats and whale oil, which handicaps the normal production and consumption of butter and lard. The Commission will hold its next meeting in 1936, in Oslo. It has been decided that the twelfth International Congress of Agriculture shall take place at The Hague in 1937.

\section{Religious Motives in Medical Biology}

IN the April issue of the Bulletin of the Institute of the History of Medicine Dr. Walter Pagel deals successively with the doctrines of Paracelsus, Hieronymus Hirnhaim, the alchemists of the seventeenth century and their adversaries, Marcus Marci, Robert Fludd, Mersenne and Robert Boyle, to illustrate the presence of religious motives in the medical biology of the seventeenth century. Dr. Pagel first shows that to Paracelsus and his religious view is due the modern conception of disease in the establishment of three new doctrines, namely: (1) the external cause is the essence of disease; (2) the organ involved and the anatomical changes decide the nature of the disease ; and (3) disease consists of a complicated disturbance of organ metabolism which secondarily reflects upon the whole system. Hirnhaim, who regarded sympathy and antipathy as fundamental phenomena, adopted a pious scepticism which was the philosophical basis of idealistic biology and pathology. On the other hand, the pious conceptions of Nature and magic in the writings of the seventeenth century alchemists led to their embarking on a course of independent empirical research, their point of view being partly due to a positive apprecia. tion of magic as a systematic imitation of Nature by means of arbitrary variation of the conditions of natural processes. After discussing the speculative embryology of Marcus Marei and his application of the physics of light to the explanation of life according to the principles of optics, Dr. Pagel gives an account of the "Medicina Catholica" of Robert Fludd, and shows at once the similarity of his conceptions with, and the fundamental differences from, the Romantic natural philosophy during the early nineteenth century. In conclusion, consideration is given to Robert Boyle and his theory of corpuscles as a scientific explanation of the mystery of specificity, forms and final causes. 